Discourse and Communication for Sustainable Education, vol. 12, no. 2, pp. 124-141, 2021

\title{
UKIDS - Trash Value: Educating With Citizenship in an Interdisciplinary Context
}

\author{
Telma André, Dárida Maria Fernandes and Maria Inês Pinho \\ Polytechnic of Porto, Porto, Portugal
}

\begin{abstract}
Supervised Teaching Practice (PES) should promote the development of skills associated with the profile of the teacher-researcher, namely: observation, recording, analysis, reflection. At the same time, it should provide children with rich and diverse experiences that produce education for (with) citizenship. The research project developed at PES was based on the European project UKIDS (Erasmus +) and was based on learning by project methodology, allowing for interdisciplinary knowledge. The challenges set in the project offer a variety of tasks to work on aspects such as initiative, motivation and innovation, as well as, trust and responsible social participation. Specifically, the Trash Value challenge, proposes to give a new life to waste, respecting a sustainable environment. Based on the implementation of this challenge and using the egg cartons, it was investigated how this material potentiated the development of social skills, reasoning and mathematical communication of children in the $4^{\text {th }}$ year of schooling. The research methodology had characteristics of action-research, selecting different techniques and instruments for data collection. In addition to the pre-test and post-test carried out on the students and the teacher in charge of the class, audio recordings, field notes, photographic records and children's productions were collected and organized in the form of multimodal narration. After conducting the study, it was possible to verify that the Trash Value challenge promoted the development of social skills, with a greater focus on cooperation, self-control and responsibility. Convergingly, problem-solving and mathematical communication skills have improved considerably, in an environment rich in children's environmental awareness.
\end{abstract}

Key words: action-research, project methodology, social skills, problem solving and mathematical communication, environmental awareness

\section{Introduction}

The research that was presented was developed in Supervised Teaching Practice (PES), within the scope of an investigative training that integrates the objectives of the Master of Education in the $1^{\text {st }}$ Cycle of Basic Education (CEB) and Mathematics and Science Natural in the $2^{\text {nd }} C E B$, during the academic year 2018/2019. 
It is an individual project with characteristics of Research-Action, which aims to develop in the master's degree the following investigative skills: observation, recording, analysis and shared reflection.

During PES a problematic situation was identified in the pedagogical area which was structured in three parts: children's difficulties in mathematics; the importance of raising children's awareness of environmental sustainability and teaching is compartmentalized, with defined hours to work in each of the areas of knowledge. Attending to the context of the research the following research question was formulated: how the "Trash Value challenge" integrated in the European Project Ukids (in which the school of Education of Porto is an institutional partner), promotes the development of social skills, reasoning and mathematical communication?

In order to answer it, the following objectives were outlined: 1) To identify the social skills developed in the operationalization of the Trash Value challenge; 2) to investigate the importance / impact of the implementation of this type of projects in the development of Reasoning and Mathematical Communication; 3) to analyze the contribution of carrying out this type of projects in awakening children's environmental awareness.

\section{Theoretical Contextualization}

\section{Social Competences}

The theme of social skills is very relevant, as it is still very poorly developed, both in terms of research and in terms of the scarce data collection instruments, with regard to validation and adaptation to the portuguese population (Baptista et al., 2011). According to Epps (as cited in Matos, Simões, \& Carvalhosa, 2000) “social competence" refers to two behavioral types: on the one hand, empathy, assertiveness, management of anxiety and anger and conversational skills that are interconnected to interpersonal behavior and, on the other hand, communication and conflict resolution. Caballo (as cited in Matos, 2000), explains that social competence is operationalized in a given interpersonal context and that it is observable by a set of behaviors that express feelings, attitudes, desires, opinions and in a way that they solve problems immediate and prevent the future.

According to Sassu (as cited in Aguiar, 2009), social competence in childhood is divided into three parameters: individual attributes, social capacities and attributes of relationship with peers. As for the individual attributes, they are linked to the child's temperament, such as empathy, the capacity for humor, among others. Social skills relate to the ability to justify one's actions, the ability to be part of a group, participate in discussions, show interest in others, etc. With regard to the attributes of relationship with peers, the authors mention, as an example, the fact that the child is usually accepted by others, is invited to play and work and is considered, in these cases, as a friend.

The interactions experienced in the child's early years with the peer group can define whether they are more or less socially competent. Canha and Neves (2008) argue that training in personal and social skills can prevent emotional problems, which is why it is necessary to develop them, from an early age, in order to improve the ability of interpersonal relationships with colleagues, the ability to solve problems, promoting health and quality of life. 
On the other hand, deficiencies in social skills can cause greater difficulties in situations of social interaction, such as building new friendships, dealing with provocations or asking for help (Matos, Simões, \& Carvalhosa, 2000).

The school is a structure of relationships and interactions where everyone should have the opportunity to be simultaneously receiver and emitter. Like this, the interaction happens in a facilitated and coordinated way, emerging the school as an agent that promotes skills in learning (Ainscow, 1998). Thus, it can be said that the school assumes a quantitative and qualitative role in the academic success of all students and plays a significant role in the acceptance and social integration of each individual (Lopes et al., 2006). On the other hand, teachers play a fundamental role in this process, and they must be, at the same time, someone who promotes learning and manages children's behaviors (Macedo, 2005).

In a complementary way, in the construction of identity and autonomy, the influence of peers is decisive in making the most of opportunities for new social relationships (Matos, 2005). Peers are part of a group of people who are grouped by characteristics, who see each other, who live and share experiences and establish contextual relationships, such as the cultural, social and personal context. However, the interaction with peers is not simple, it is a complex dynamic, since there are numerous variables that influence the individual and their social interaction (Dias, 2004).

On the other hand, according to Caldarella and Merrell (as cited in Rocha, 2008), it was found that the deficit in social skills, especially those related to acceptance by peers and teachers, are strongly linked with a set factors that predispose the child to adopt violent and antisocial behaviors. Children who have difficulty adapting either in the teacher(s)-student relationship, or in the relationship with their peers, the probability of having academic, social and emotional problems is increased, which can later cause delinquent and aggressive behaviors. On the other hand, positive forms of social behavior provide a classroom environment that allows for better learning. In the same way that positive interpersonal relationships with teachers and peers can motivate and support the development of intellectual skills (Wentzel, 2003; as cited in Rocha, 2008).

According to Lopes et al. (2006), the teaching of social skills should not be carried out in specific subjects for this purpose, but should be carried out by all teachers, in all classes and at all times.

As Lerbert (1999) points out, the student does not work in a strictly rationalist way, because to solve a problem, he interconnects the various knowledge learned and puts it into action. In this process, the operationalization of personal and social skills and not just scientific knowledge occurs. In this context, it is referred that Wenger (as cited in Fernandes, 2006), defends a social theory of learning in which four components are included: the meaning, which concerns the human being's capacity and need to find a meaning for its existence; the practice is related to the experience and sharing of perspectives and resources; the community is where initiatives are expressed and where the individual's participation is recognized and identity which is related to the creation of the individual's own identity.

\section{Mathematical Reasoning}

For Kilpatrick and Swafford (2004) "Reasoning is the glue that keeps mathematics together"(p. 14) and Mota (2014), explains this statement stating that "it is what allows 
us to establish, in a logical way, the link between previous premises or ideas and conclusions"(p. 15). For Russel (1999), mathematical reasoning is "[used] to think about the properties of mathematical objects and to develop generalizations that apply to the whole class of objects, "thus building "an interconnected web of mathematical knowledge within a mathematical domain" (p. 1). Janela (2012) states that this ability allows the construction of the meanings of students' mathematical ideas. In this way, students learn when they integrate new knowledge in the set of what they already have. On the other hand, Boavida (2008) considers that "reasoning refers to calculating, but also the use reason to judge, understand, examine, evaluate, justify and conclude"(p. 1). Thus, "it appears that reasoning is not only when calculating procedures are carried out, but also and above all, when analyzing and arguing about the coherence of the options that have been implemented" (Mota, 2014, p. 15).

NCTM (2008) highlights that mathematical reasoning is an integral part of this discipline, being an area in which students "reason and think analytically" (p. 61), detecting patterns and regularities, formulating and validating their own conjectures, building and evaluating their arguments and, finally, explaining and justifying the results obtained by them. It is considered important to note that this ability is also developed in the argumentation process, as this is where different facets of thought are consciously evaluated and tested. When arguing, we look for answers that, in addition to being true, validate our convergent way of thinking (Assumpção, 2011).

With regard to types of reasoning to be used in mathematics class, Azevedo (as cited in Oliveira, 2002) describes and defends four types of reasoning: induction, deduction, abduction and transformation.

Within the scope of this study and based on the literary review presented, mathematical reasoning is assumed as a cognitive operation that involves the use of different thinking capacities such as explaining, justifying, arguing and / or demonstrating mathematical facts and procedures so that the subject can clarify yourself about the paths to follow, as well as to elucidate others of the options you have taken.

\section{Mathematical Communication}

It is through communication that the child is encouraged to communicate and share knowledge, using the language of mathematics (Fernandes, 2006).

NCTM (2007, p. 66) highlights communication as "an essential part of mathematics and mathematics education. It is a way of sharing ideas and clarifying mathematical understanding." The development of Mathematical Communication can happen from the involvement of students in discussions about mathematical ideas, reasoning developed and results achieved, among other situations in a mathematics class (Pimenta, 2013).

In the Basic Education Mathematics Program (PMEB), it is valued "the ability of students to communicate their mathematical ideas and to interpret and understand the ideas of others, participating in discussions about mathematical ideas, processes and results" (Guerreiro, 2010, p. 211). The PMEB confers three functions to Mathematical Communication, as it is seen as: i) fundamental curricular objective in the subject of mathematics; ii) content, insofar as it constitutes one of the transversal capacities to be promoted by the teacher (in addition to the other two capacities: problem solving and Mathematical reasoning), in conjunction with mathematical themes and iii) the teacher's 
teaching and students learning methods (Amaral et al., 2010; Cabrita et al., 2010; Medeiros \& Ponte, 2010; Menezes, 2010; Ponte, 2008; Sousa, 2009).

It also highlights the important role of argumentation in mathematical communication. The argumentation process is closely linked to the relevance of developing the ability to develop mathematical reasoning and to learn mathematics with understanding, resulting from mathematical justifications and explanations based on the rationale for reasoning, discoveries, conjectures, mathematical tests (among others) (Boavida et al., 2008; Cabrita et al., 2010; Rodrigues, 2010).

The teacher must give importance to the mathematical reasoning of the students and, consequently, stimulate their explanation and analysis, in a clear and rigorous way; and, foster student involvement in the face of colleagues' reasons (Sousa, 2009; Pinto \& Santos, 2010).

In a similar line of thought, Fernandes (2006), states that children should be challenged to develop thinking, reasoning and mathematical communication, which is essential to be able to express, both orally and in writing, the learning paths, that is, the processes and reasoning used, as well as the results obtained.

\section{Environmental Education for Sustainability}

In Portugal, the development of Environmental Education has arisen from the transition from a mostly rural society, which did not have a major negative influence on the environment, to a modern society, but without an adequate modernization process (Schimdt, 2005). From the moment that the themes related to Environmental Education began to be integrated in several school textbooks, they become increasingly present in social awareness.

In recent decades, the term Environmental Education has been replaced by the term Education for Sustainable Development, due to the promotion of UNESCO's Decade of Education for Sustainable Development (Schimdt et al., 2008; Heasly et al., 2020). Currently, Environmental Education for Sustainability is included in Education for Citizenship Environmental Education or Education for Sustainable Development is understood "... as a permanent learning process that seeks to increase information and public knowledge about environmental problems, while promoting the critical sense of populations" (Schimdt et al., 2008, p. 3).

Since the 8 proposed Millennium Development Goals (2000-2015) did not fully achieve the goals they set themselves, the 2030 Agenda was created. In the 2030 Agenda, 17 Millennium Development Goals were defined, to be achieved by 2030, which make clear the urgency of promoting the well-being of the world's populations, through environmental protection. It is noteworthy that among the 17 defined objectives, 6 have a connection to the environment, namely: renewable and accessible energy, sustainable cities and communities, sustainable production and consumption, climate action, protection of marine life and protection of terrestrial life (UN, 2015).

In view of the above, it is justified the importance of articulating the syllabus contents of the different curricular areas, with the principles of Environmental Education or Education for Sustainable Development, as a means to form ecologically conscious citizens, interested in making a difference in the society in which they live. Specifically, environmental protection and conservation are essential for the well-being of the world population today and in the future (Mateus, 2018). 
As for the didactic-pedagogical strategies to address the theme of Environmental Education, they must be integrative and not compartmentalized by areas of knowledge. In this operationalization some difficulties can be found. Giordan and Souchon (1997) affirm that the main difficulties are related to the adjustment of school hours and recess times, the insufficient number of reception facilities on the ground (outside the school grounds) and the underutilization of those that exist. They also mention a less active participation on the part of teaching professionals and the lack of qualified personnel to promote complementary activities.

According to DGE (2018) Environmental Education is an integral part of education for citizenship, assuming, due to its intrinsically transversal characteristic, a privileged place in the promotion of attitudes and values, as well as in the development of essential skills to respond to society's challenges. which results in sustainable behaviors in all dimensions of human activity.

\section{Methodology}

The choice of an adequate research methodology is crucial to achieve the proposed objectives. In this case, the research methodology adopted is based on a scheme with characteristics of Research-Action. According to Latorre (2003), this methodology has a symbiosis relationship with education, being the one that comes closest to the educational environment, assuming the teacher as a researcher. Elliot (1991), on the other hand, defines Action-Research as a study of a social situation that aims to improve its quality of action. According to Ribeiro (2018), the Action-Research methodology assumes itself as a model to improve the relationship between theory and professional self-training structured in five stages: (1) the first stage is defined by feeling and experiencing a problem; (2) the second stage is imagining the solution to the problem identified; (3) the third is cutting the imagined solution into practice; (4) the fouth is evaluating the results of the actions developed; (5) the fifth is modifying the practice based on the results obtained.

The work carried out follows a qualitative methodology, in which the theory is of an interpretative nature, that is, it does not precede the data, but arises from the data itself, in a close constant and dynamic relationship with practice (Coutinho, 2011).

Although observation and interviews are the methods commonly used, in this type of study no method is excluded, as the techniques for collecting information are chosen according to their suitability for the task in question (Bell, 1997).

Participant observation (the one whose observer participates in the life of the group he is studying, and the observer plays a well-defined role in the social organization he observes) will be carried out (Estrela, 1990).

\section{Research Participants}

The present research project took place in the group of schools in which the master's student carried out his Supervised Teaching Practice (PES) during the $2^{\text {nd }}$ semester of the academic year 2018/2019, in a Basic School of the $1^{\text {st }}$ cycle, with a class of $4^{\text {th }}$ year of schooling.

The participants in the project are 23 students from a 4th grade class, 12 of which are female and 11 are male. The children in the class were aged between 9 and 11 years old and contacted the master student 3.5 days a week. 
The class is characterized by being interested and participative. At the social level, there are conflicts within the class, with difficulties in interaction between children. The context has a close relationship with the family and the community in general, sharing several activities.

\section{Data Collection Techniques and Tools}

In order to collect relevant information for the investigation, a set of techniques and data collection instruments were selected. Bogdan and Biklen (2013) say that "the term data refers to raw materials that researchers collect from the world they are studying; they are the elements that form the basis of the analysis"(p. 149).

The techniques and instruments to be applied depend on the nature of the study and, above all, on the objectives of the study (Coutinho, 2011). In this sense, the present investigative study used different techniques and data collection instruments that are presented below.

Participant observation is dynamic and engaging and the researcher is both an instrument in data collection and interpretation. The fact of being integrated in the environment where the action under study is developed, means that the researcher's interactions with that context, in this case the students in the class, may influence the data that is being collected. Nevertheless, Bogdan and Biklen (2013) argue that participant observation is a "qualitative research technique suitable for the researcher who wishes to understand a social environment that, from the outset, is foreign or foreign and that allows him to progressively integrate into activities of the people who live in it" (p. 155).

During conducting of the study, the behaviors and attitudes of students in the context of work in the classroom were observed, from the interactions between the members of each group, and the development of the proposed tasks, and field notes were also made in the form logbook, photographic records and audio recordings.

A questionnaire was applied to the children and to the cooperating teacher, filled out individually, in two different moments: one before starting the project implementation and another after the conclusion of the project, functioning as pre and post-test respectively. In parallel, students' productions were also analyzed during the sessions.

Taking into account the instruments presented for data collection, a Multimodal Narration (NM) was built. NM assumes itself as a means of “... organizing and transforming data collected within the classroom in order to preserve its fullness and complexity, making it useful for teaching, professional development and research" (Lopes et al., 2013, p 34.)

The use of NM emerged from the need to look at this project in a holistic way, being essential to include the decisions of the teacher, the contributions of the students and the work that was really developed in the class, with the objective of enabling the most accurate collection of data of the classroom.

\section{Data Collection Procedures}

The research project was based on the "Trash Value" challenge, having been properly adapted, meeting the characteristics of the class and the objectives defined for the present investigative study. 
The "Trash Value" challenge, translated into Portuguese as "The value of garbage," proposes to give garbage a new life. Taking into account the scope of this work, there was a need to mark the type of garbage, so the choice fell on the egg cartons.

In view of the interdisciplinary nature of this project, it was decided to apply the different activity proposals over six sessions, which took place during approximately 1 month (May 8 to June 4). Each session had a different duration, taking into account the objectives established for each session. The schedule of the intervention performed is shown in Table 1.

\section{Table 1}

Representative Schedule for the Implementation of the Project

\begin{tabular}{|c|c|c|c|}
\hline $\begin{array}{l}\text { Session } \\
\text { number }\end{array}$ & Date & $\begin{array}{l}\text { Duration } \\
\text { (minutes) }\end{array}$ & Developed activities \\
\hline 1 & $08 / 05 / 2019$ & 45 & $\begin{array}{l}\text { General presentation of the project to the class; } \\
\text { Application of the pre-test to children and cooperating } \\
\text { teacher (Pre-test - based on an adaptation for the Portu- } \\
\text { guese population of the KIDSCREEN } 10 \text { questionnaire } \\
\text { (reformulated by Gaspar \& Matos, 2008) and the Healhty } \\
\text { kids Resilience Assessment Module, adapted by Martins } \\
\text { (2002) and the program for the promotion of social skills } \\
\text { adapted from the Manual for the Promotion of Resilience } \\
\text { in Adolescence (Simões et al., 2009). }\end{array}$ \\
\hline 2 & $14 / 05 / 2019$ & 90 & $\begin{array}{l}\text { Visualization of a PowerPoint illustrating the project; } \\
\text { Formation of working groups; } \\
\text { Project idea decision; } \\
\text { Start of filling out the action plan. }\end{array}$ \\
\hline 3 & $22 / 05 / 2019$ & 45 & $\begin{array}{l}\text { Arrival of egg cartons to the classroom; } \\
\text { Planning of activities to be carried out by each group. }\end{array}$ \\
\hline 4 & 29/05/2019 & 1 dia & $\begin{array}{l}\text { Study visit to the exhibition by Joana Vasconcelos entitled } \\
\text { "I m Your Mirror", at Serralves house. }\end{array}$ \\
\hline 5 & $31 / 05 / 2019$ & 90 & $\begin{array}{l}\text { Oral presentation of the work - Status report; } \\
\text { Completion of project planning; } \\
\text { Execution of the work plan. }\end{array}$ \\
\hline 6 & 04/06/2019 & 45 & $\begin{array}{l}\text { Finalization of the works; } \\
\text { Construction of the project's technical file; } \\
\text { Reflection on the project - key phrase; } \\
\text { Delivery of questionnaires to parents and guardians; } \\
\text { Challenge children to build other objects at home; } \\
\text { Post-test application to children and cooperating teacher. }\end{array}$ \\
\hline
\end{tabular}

The planning of the project was built in an articulated way, based on essential learning and where a strong connection of knowledge is described, based on a multidisciplinary team from the Areas of Visual Education, Natural Sciences and Mathematics, which focused on the design and the planning of the research project to be implemented in the field.

In this research The authors have tried to compare the results obtained in the pretest and post-test by crossing the results with the other data collection instruments, in 
order to answer the problem question and the objectives placed in the initial phase of this investigative work.

During the second session, in addition to the organization of the working groups, the choice of the theme for each project started by completing the Action Plan. In the third session, the Action Plan was completed as well as a motivating action was implemented by promoting the involvment of all children from the classroom. A study visit was also organized to the Joana Vasconcelo's “I'm Your Mirror” exhibition at Serralves house.

Taking into account the difficulty presented by the children in recording what they intended to do, in the $5^{\text {th }}$ session, all groups made the state point of the work done by each group. After completing the planning, the children started to execute the plan.

In the last session, after finishing the work, each group have built the technical file of their work. Each group was also challenged to reflect on the path taken by writing a sentence that reflected it. A questionnaire was sent to the Parents and children were challenged to build other objects at home. Finally, the post-test was applied.

\section{Research Findings}

Based on the different data collection instruments, this item intends to present and reflect on the results obtained in this investigation based on the project work developed in group with the Trash Value challenge, using egg cartons.

This first analysis is based on the results obtained in the pre and post test and shown in Table 2.

\section{Table 2}

Comparative Analysis of the Data Obtained in the Pre-test and in the Post-test With Regard to Reasoning and Mathematical Communication in Action on the Problem, on Two Levels ("Always" and "Many Times")

\begin{tabular}{|c|c|c|c|c|c|c|}
\hline \multirow[b]{2}{*}{ Items } & \multicolumn{2}{|c|}{ "Always" } & \multirow[b]{2}{*}{ Balance } & \multicolumn{2}{|c|}{ "Often" } & \multirow[b]{2}{*}{ Balance } \\
\hline & $\begin{array}{c}\text { Pre-test } \\
(\%)\end{array}$ & $\begin{array}{c}\text { Post-test } \\
(\%)\end{array}$ & & $\begin{array}{l}\text { Pre-test } \\
(\%)\end{array}$ & $\begin{array}{l}\text { Post-test } \\
(\%)\end{array}$ & \\
\hline $\begin{array}{l}\text { Be creative in an idea to find the } \\
\text { solution to the problem }\end{array}$ & 0 & 39 & $39 \uparrow$ & 48 & 48 & 0 \\
\hline Be creative in applying that idea & 35 & 22 & $13 !$ & 22 & 43 & $21 \uparrow$ \\
\hline Explain my reasoning & 30 & 39 & $9 \uparrow$ & 17 & 61 & $44 \uparrow$ \\
\hline Justify my reasoning & 26 & 39 & $13 \uparrow$ & 30 & 48 & $18 \uparrow$ \\
\hline Argue (defend the idea) & 22 & 39 & $17 \uparrow$ & 30 & 52 & $22 \uparrow$ \\
\hline $\begin{array}{l}\text { Generalize (apply knowledge } \\
\text { prior to solving the new problem) }\end{array}$ & 13 & 43 & $30 \uparrow$ & 39 & 30 & $9 !$ \\
\hline $\begin{array}{l}\text { Being objective (aiming to solve } \\
\text { the problem) }\end{array}$ & 35 & 35 & 0 & 22 & 48 & 261 \\
\hline
\end{tabular}

This can be seen in the Table, at the "always" level, there was a greater increase in the parameter "be creative in an idea to find the solution to the problem" where the percentage of responses went up $39 \%$. This was followed by the largest increase $(30 \%)$ in the ability to "generalize (apply knowledge prior to solving the new problem)." On 
the other hand, the parameter "be creative in applying this idea" showed a lower percentage in the post-test than in the pre-test in terms of the "always" assessment $(13 \%)$. These results show that children, after implementing the project, are able to be more creative, however they still have difficulties in operationalizing their ideas, which reveals to be quite realistic, given that knowing how to do is more complex than knowing how to say. This may be explained by the fact that they are more aware of everything that is necessary to put an idea into practice, having been experienced by the child during the realization of the project, from conception to its implementation.

As for the objective related to the development of Reasoning, the highest increase occurred in the parameter "explain my reasoning," with a positive increase of $44 \%$. It is considered that during the realization of the project the children had freedom and the opportunity to speak and communicate their ideas and suggestions, for example, when presenting their projects, having been an opportunity to train and consequently develop the competence of "Explain my reasoning". This was followed by "being objective (aiming to solve the problem)" with a $26 \%$ increase, also quite significant, which shows that children consider, at the end of the project, to have developed this competence. On the other hand, children admit to being able to make generalizations less frequently: there was a $30 \%$ increase in "always", and everything indicates that there seems to have been, for this level, a transfer from the always level to "oftentimes".

Table 3 shows that the data obtained in the pre-test and in the post-test regarding the self-reflection process in solving problems in two more significant parameters.

\section{Table 3}

Comparative Analysis of the Data Obtained in the Pre-test and in the Post-test With Respect to Mathematical Reasoning and Communication in the Self-reflection Process, on Two Levels ("Always" and "Many Times")

\begin{tabular}{|c|c|c|c|c|c|c|}
\hline \multirow[b]{2}{*}{ Items } & \multicolumn{2}{|c|}{ "Always" } & \multirow[b]{2}{*}{ Balance } & \multicolumn{2}{|c|}{ "Often" } & \multirow[b]{2}{*}{ Balance } \\
\hline & $\begin{array}{c}\text { Pre-test } \\
(\%)\end{array}$ & $\begin{array}{c}\text { Post-test } \\
(\%)\end{array}$ & & $\begin{array}{c}\text { Pre-test } \\
(\%)\end{array}$ & $\begin{array}{c}\text { Post-test } \\
(\%)\end{array}$ & \\
\hline $\begin{array}{l}\text { The solution found is the correct } \\
\text { answer to the problem }\end{array}$ & 30 & 35 & $5 \uparrow$ & 30 & 48 & $18 \uparrow$ \\
\hline There are other solutions & 43 & 35 & $8 \downarrow$ & 26 & 35 & $9 \uparrow$ \\
\hline $\begin{array}{l}\text { There are other resolution } \\
\text { strategies that can be applied }\end{array}$ & 22 & 48 & $26 \uparrow$ & 48 & 48 & 0 \\
\hline $\begin{array}{l}\text { I was able to understand the } \\
\text { problem solving process, from the } \\
\text { idea to finding the solution }\end{array}$ & 13 & 48 & $35 \uparrow$ & 39 & 43 & $4 \uparrow$ \\
\hline
\end{tabular}

Comparing the answers given by the children in the pre-test and in the post-test, at the "always" level there was a huge positive increase in the parameter "I was able to understand the process of solving the problem, from the idea to the discovery of the solution," going up to $35 \%$.

As for the opinion of the cooperating teacher regarding Self-reflection, the differences between the initial and final capacities show a positive balance. This means that the frequency with which each child performs each parameter has increased: what they initially did "rarely" started to be done "sometimes" and what happened "sometimes" started 
to be done "many times". The second parameter that rose the most, about $26 \%$, was "there are other resolution strategies that can be applied". After taking the challenge, the children became aware of the constraints associated with problem solving, as in the responses to the post-test they speak with knowledge of the cause. On the "many times" scale, the parameter that registered the greatest increase was "the solution found is the correct answer to the problem" from $30 \%$ to $48 \%$. The remaining parameters registered a slight increase, except for the parameter "there are other resolution strategies that can be applied", which remained true.

With regard to 'Reasoning' and 'Mathematical Communication', everything indicates that children, when participating in this type of work, namely in this challenge, felt greater openness in the concept of "problem" and acquired a greater capacity to act and find a solution. It can also be said that, in general, children assumed they were able to perform the tasks inherent to the problem-solving process more often in the post-test than in the pre-test. The opinion of the cooperating teacher, in these parameters, is also convergent with the opinions shown by the children. In this way, it can be inferred that the implementation of the project improved the children's ability to solve mathematical problems, both in terms of the resolution itself, as well as in the self-reflection process.

The second part of the questionnaire addresses social skills, asking children to give their contribution on what they feel they are capable of when working in a group: "When I work in a group I feel that I am capable of..."

Table 4 shows the data obtained in the pre-test and in the post-test with regard to social skills, at the two most significant levels.

\section{Table 4}

Comparative Analysis of the Data Obtained in the Pre-test and in the Post-test With Respect to Social Skills, in Two Levels ("Always" and "Many Times")

\begin{tabular}{|c|c|c|c|c|c|c|c|}
\hline \multirow[b]{2}{*}{ Items } & \multirow{2}{*}{ Scale } & \multicolumn{2}{|c|}{ "Always" } & \multirow[b]{2}{*}{ Balance } & \multicolumn{2}{|c|}{ "Often" } & \multirow[b]{2}{*}{ Balance } \\
\hline & & $\begin{array}{l}\text { Pre-test } \\
(\%)\end{array}$ & $\begin{array}{c}\text { Post-test } \\
(\%)\end{array}$ & & $\begin{array}{c}\text { Pre-test } \\
(\%)\end{array}$ & $\begin{array}{c}\text { Post-test } \\
(\%)\end{array}$ & \\
\hline Assertiveness & Be objective & 17 & 48 & $31 \uparrow$ & 39 & 43 & $4 \uparrow$ \\
\hline \multirow[t]{2}{*}{ Self-control } & Control what I feel & 22 & 39 & $17 \uparrow$ & 35 & 35 & 0 \\
\hline & Control what I do & 35 & 30 & $5 \downarrow$ & 26 & 48 & $22 \uparrow$ \\
\hline \multirow{3}{*}{$\begin{array}{l}\text { Creativity } \\
\text { Responsability }\end{array}$} & Have ideas & 43 & 48 & $5 \uparrow$ & 35 & 39 & $4 \uparrow$ \\
\hline & $\begin{array}{l}\text { Become aware of } \\
\text { the risks }\end{array}$ & 35 & 48 & $13 \uparrow$ & 35 & 35 & 0 \\
\hline & Take on tasks & 35 & 48 & $13 \uparrow$ & 22 & 35 & $13 \uparrow$ \\
\hline \multirow[t]{2}{*}{ Cooperation } & $\begin{array}{l}\text { Respect the opinions } \\
\text { of colleagues crea- } \\
\text { ting empathy }\end{array}$ & 39 & 22 & $17 \downarrow$ & 26 & 57 & $31 \uparrow$ \\
\hline & $\begin{array}{l}\text { Acting on behalf of } \\
\text { the group }\end{array}$ & 30 & 30 & 0 & 30 & 39 & $9 \uparrow$ \\
\hline \multirow[t]{2}{*}{ Critical spirit } & Accept criticism & 35 & 35 & 0 & 17 & 48 & $31 \uparrow$ \\
\hline & Try to improve & 61 & 65 & $4 \uparrow$ & 22 & 26 & $4 \uparrow$ \\
\hline Autonomy & $\begin{array}{l}\text { Take initiative to } \\
\text { perform tasks }\end{array}$ & 26 & 30 & $4 \uparrow$ & 35 & 52 & $17 \uparrow$ \\
\hline
\end{tabular}


It is observed that in most situations, children in the post-test admit being able to perform observable social behaviors more often than in the pre-test, except for two situations, both at the "always" level: in the "self-control - controlling what I do" and in "cooperation - respect the opinions of colleagues creating empathy" in which there was a decrease of $5 \%$ and $17 \%$, respectively. "Assertiveness - to be objective" was the observable behavior that registered the greatest increase $(31 \%)$, at the "always" level. As for the "many times" level, the biggest increase registered was in "Spirit-critic accept criticism" with an increase of $31 \%$. These climbs can be related to the constant group work carried out throughout the project, which made the children able to develop the competence of "Assertiveness" and "Spirit-Critic". Crossing the opinion of the children with the opinion of the cooperating teacher, the most developed social skills during the project were "Self-control" and "Cooperation".

The responses to the Action Plan were compiled, making a comparative analysis of the responses of each group. In general, it was found that all groups take longer than expected, showed difficulties and weak motivation to carry out planning. However, despite not being used to performe this type of task, it was completed by everyone.

Along with the Action Plan, children were asking for scratch sheets to make their notes, records and diagrams. The parents were also involved in this project since they were invited to help their children. This involvment together with the children motivation induced by this project led to an awareness of environmental issues. This is particularly visible in the statements made by the children, where the ecological issue was commonly cited.

As for the questionnaires made available to parents, they considered that the most developed skills in carrying out this project were "Argumentation", "Objectivity", "Selfreflection" and "Cooperation".

\section{Conclusions}

The implementation of this project resulted in a very positive balance, having fulfilled the proposed objectives in a meaningful and in-depth way.

As for "Reasoning and Mathematical Communication", the children admit that they feel capable of carrying out, in general, the proposed descriptors, both for "action on the problem" and for "self-reflection".

Regarding "social skills" the pattern is the same since the children considered performing the observable behaviors proposed after carrying out the project work on the Trash Value, in a significant environmental awareness and acquired in a group. In a perspective of data triangulation and validation of the results obtained, the cooperating teacher reinforces the same line of thought, considering that there has been an improvement in the relationship with the other and a greater awareness of the need to build a sustainable environment. The remaining data collection instruments are also convergent in these parameters, and it can be concluded that children were able to take positive attitudes in the context of the development of the proposed social skills, experiencing them more frequently in the different phases of the realization of this project.

With regard to social skills, "Cooperation" and "Self-control" were considered by the children in the class and by the cooperating teacher, as the most developed skills during the realization of the Trash Value challenge. 
With regard to "Mathematical Reasoning" and "Communication", it can be said that children assumed to be able to perform the tasks inherent in the problem solving process more frequently after the implementation of this project. The cooperating teacher corroborated this idea and said that they became more receptive to problem solving. The parameter in which there was a more positive evolution was "to be creative in an idea to discover the solution to the problem", followed by "generalize (apply knowledge prior to solving the new problem)". It can thus be said that the implementation of these types of projects related to entrepreneurship and environmental sustainability are significant for children. Through them they have the opportunity to develop Reasoning and Mathematical Communication, as children have to share ideas to conceive the project, as well as in its realization and presentation to the class. In this way, it can be inferred that the implementation of the project improved the children's ability to solve mathematical problems, both in terms of the resolution itself, as well as in the self-reflection process.

Despite being outside the scope of the study, it can still be said that after the implementation of the challenge, the frequency of occurrence of conflicts within the class dropped considerably. In this context, a clue is launched for future investigations, as it would be interesting to see to what extent, the methodology of project work and specifically this type of projects improves the relationship between the children in the class. In fact, there are children who find it very difficult to accept the opinions of their colleagues and to cooperate in groups and this type of work promotes the sharing of ideas and the construction of a common decision. On the other hand, as all working groups showed great difficulty in planning the project, they were initially reluctant to carry it out and willing to refuse its written record, with the children saying that they did not want to write, wanting to move on immediately "to the action to do". Thus, everything indicates that it would be interesting to carry out further research in these educational contexts. In addition to the difficulty in writing what they think, when there are several ideas in a group, it was not easy to decide which ideas to select in the groups.

The study visit to Serralves was also a high point of motivation for these children, sharpening their taste and interest in art. They began to look at their own works with much more interest, as if they were works of art. In addition to the fact that they were using materials that were no longer valuable, they were garbage and were now being transformed into works of art!

The final sentences for concluding the projects speak of the environmental character of this type of art, meeting the third objective defined for this investigative study. Two groups used the word creativity to complete their project, thus indicating that this competence was strongly encouraged throughout the project's implementation path.

On the other hand, this project allowed a closer connection with the family, reinforcing the involvement of parents and guardians in the children's learning process.

The implementation of this type of projects / challenges allows operationalizing the integration and articulation of the curriculum, resulting in more meaningful learning for children. 


\section{References}

Aguiar, T. (2009). Competências de literacia de numeracia e sociais no pré-escolar e no $1^{\circ}$ ano de escolaridade - Um estudo sobre a sua configuração e evolução. Tese de Mestrado em Temas de Psicologia. Universidade do Porto, Faculdade de Psicologia $e$ de Ciências da Educação, Porto [Numeracy and social literacy skills in pre-school and in the first year of schooling - a study on its configuration and evolution. Master's Thesis in Psychology Themes].University of Porto, Faculty of Psychology and Educational Sciences, Porto.

Ainscow, M. (1998). Necessidades Especiais na sala de aula. Um guia para a formação de professores. Instituto de Inovação Educacional [Special needs in the classroom. A guide for teacher training. Educational Innovation Institute]. Lisboa: Edições UNESCO.

Amaral, N., Carreira, S., \& Amado, N. (2010). A resolução de problemas e a comunicação matemática para além da sala de aula: como vêm os alunos o uso das tecnologias? In J. Matos, A. Domingos, C. Carvalho, \& P. Teixeira (Eds.), Investigação em educação matemática: Comunicação no ensino e aprendizagem [Problem solving and mathematical communication beyond the classroom: How do students see the use of technology?]. Lisboa.

Assumpção, A. L. (2011). O ensino da Matemática e o desenvolvimento do raciocínio lógico - um estudo introdutório. XIII CIAEM-IACME [The teaching of mathematics and the development of logical reasoning - an introductory study. XIII CIAEM IACME]. Brasil: Recife. http://www.gente.eti.br/lematec/CDS/XIIICIAEM/ artigos/1335.pdf

Baptista, N. J., Monteiro, C. A., Silva, M. O., Santos, F. A., \& Sousa, I. S. (2011). Programa de promoção de competências sociais: Intervenção em Group com alunos do $2^{\circ} \mathrm{CEB}$. [The teaching of mathematics and the development of logical reasoning an introductory study]. Brasil: Recife. https://xiii.ciaem-redumate.org/index.php/ xiii_ciaem/xiii_ciaem/paper/viewFile/1335/894

Bell, J. (1997). Como realizar um projeto de investigação: um guia para a pesquisa em ciências sociais e da educação [How to carry out a research project: A guide for research in social sciences and education]. Gradiva: Lisboa.

Boavida, A. M., Paiva, A. L., Cebola, G., Vale, I., \& Pimentel, T. (2008). A experiência matemática no ensino básico. Programa de formação contínua em matemática para professores dos $1 .^{\circ} \mathrm{e} 2 .^{\circ}$ ciclos [The mathematical experience in basic education. Continuing education program in mathematics for teachers in the $1^{\text {st }}$ and $2^{\text {nd }}$ cycles]. Lisboa: Ministério da Educação - DGIDC.

Bogdan, R., \& Biklen, S. (2013). Investigação qualitativa em educação [Qualitative investigation in education]. Porto: Porto Editora.

Cabrita et al. (2010). Experiências de aprendizagem matemática significantes [Significant mathematical learning experiences]. Aveiro: Universidade de Aveiro. http://hdl. handle.net/10773/9792

Canha, L., \& Neves (2008). Programa de treino de competências pessoais e sociais desenvolvimento de um modelo adaptado a crianças e jovens com deficiência [Personal and social skills training program - development of a model adapted to children and young people with disabilities]. Lisboa: Instituto Nacional para a Reabilitação. 
Coutinho, C. (2011). Metodologia de investigação em Ciências Sociais e Humanas: Teoria e Prática [Research methodology in social and human sciences: Theory and practice]. Coimbra: Almedina.

Dias, N. F. (2004). Relações grupais e desenvolvimento humano. Epistemologia e Sociedade. Group relations and human development [Epistemology and society]. Lisboa: Instituto Piaget.

Direção Geral da Educação. (2018). Referencial de educação ambiental para a sustentabilidade para a Educação Pré-Escolar, o Ensino Básico e o Ensino Secundário [Environmental education benchmark for sustainability for Pre-School Education, Basic Education and Secondary Education]. Lisboa: Ministério da Educação.

Elliot, J. (1991). Action research for educational change. Bristol: Open University Press. Estrela, A. (1990). Teoria e Prática de Observação de Classes - uma estratégia de formação de professores [Class observation theory and practice - a teacher training strategy] ( $3^{\text {rd }}$ Ed.). Lisboa: Instituto Nacional de Investigação Científica.

Fernandes, D. (2006). Aprendizagens algébricas em contexto interdisciplinar no ensino básico. Tese de Doutoramento em Didática [Algebraic learning in an interdisciplinary context in basic education. Doctoral thesis in didactics]. Aveiro: Universidade de Aveiro.

Gaspar, T. M. (2008). Qualidade de vida em crianças e adolescentes. Versão portuguesa dos instrumentos Kidscreen 52. [Quality of life in children and adolescents. Portuguese version of Kidscreen 52 instruments]. Cruz Quebrada: Aventura Social e Saúde.

Giordan, A., \& Souchon, C. (1997). Uma educação para o ambiente [Education for the environment]. Mem Martins (Sintra): Instituto de Inovação Educacional/Instituto de Promoção Ambiental.

Guerreiro, A. (2010). O papel do outro (aluno) na comunicação matemática: práticas de uma professora do $1 .^{\circ}$ ciclo [The role of the other (student) in mathematical communication: Practices of a teacher in the $1^{\text {st }}$ cycle]. In J. Matos, A. Domingos, C. Carvalho, \& P. Teixeira (Eds.), Investigação em educação matemática: comunicação no ensino e na aprendizagem [Research in mathematics education: communication in the teaching and learning]. Lisboa: Sociedade Portuguesa de Investigação em Educação Matemática.

Guerreiro, A., \& Menezes, L. (2010). Comunicação matemática: na busca de um entendimento comum [Mathematics communication: In search for a common understanding]. In Actas do XII Seminário de investigação em educação matemática [XII Investigation Seminar in Mathematics Education]. Lisboa: APM.

Heasly, B., Iliško, Dz., Salìte, I., \& Lindner, J. (2021). Looking beyond, looking together, looking collaborately, facing the future. Discourse and Communication for Sustainable Education, 12(1), 1-4. doi: 10.2478/dcse-2021-0001

Janela, M. (2012). O (Novo) Programa de Matemática do Ensino Básico e o desenvolvimento do raciocínio geométrico no tópico Triângulos e quadriláteros [Basic Education Mathematics Program and the development of geometric reasoning in the topic triangles and quadrilaterals]. http://repositorio.ul.pt/bitstream/10451/6323/ 1/ulfpie040086_tm.pdf

Kilpatrick, J., \& Swafford (2004). Adding it up: Helping children learn mathematics. Washington, DC: National Academy Press. 
Latorre, A. (2003). La Investigación-Accion [Research-action]. Barcelo: Graó. Lisboa: Gradiva.

Lerbert, G. (1999). Transdisciplinaridade e educação [Transdisciplinarity and education]. Lisboa: Instituto Piaget.

Lopes, J. B., Silva, A., Cravino, J., \& Santos, C. (2013). Constructing and using multimodal narratives to research on science education: Contributions based on classroom practices. Research in Science Education, 44, 415-438.

Lopes, J., Rutherford, R., Cruz, M., Mathur, S., \& Quinn, M. (2006). Competências Sociais: aspetos comportamentais, emocionais e de aprendizagem [Social skills: Behavioral, emotional and learning aspects]. Braga: Psiquilibrios Edições.

Macedo, L. (2005). Ensaios Pedagógicos: como construir uma escola para todos? [Pedagogical Essays: How to build a school for everyone?]. Porto Alegre: Artmed.

Mateus, D. M. (2018). A importância da educação geográfica para a educação ambiental. Uma experiência didática no 9. ano. Relatório de Prática de Ensino Supervisionada do Mestrado em Ensino de Geografia no $3 .^{\circ}$ ciclo do Ensino Básico e no Ensino Secundário [The importance of geographic education for environmental education. A didactic experience in the $9^{\text {th }}$ year. Supervised teaching practice report of the Master in Geography teaching in the $3^{\text {rd }}$ cycle of basic education and in secondary education]. Lisboa: Universidade de Lisboa.

Matos, M. (2005). Comunicação, Gestão de conflitos e Saúde na escola. [Communication, conflict management and health at school]. Cruz Quebrada (Lisboa): Faculdade de Motricidade Humana Edições.

Matos, M. (2000). Desenvolvimento de competências de vida na prevenção do desajustamento social. Lisboa: Faculdade de Motricidade Humana/Instituto de Reinserção Social - Ministério da Justiça. Col. Aventura social e Risco [Development of life skills in preventing social maladjustment]. Lisbon: Faculty of Human Motricity/ Social Reinsertion Institute - Ministry of Justice. Col. Social adventure and Risk.

Medeiros, K., \& Ponte J. (2010). Explicar e negociar significados: as concepções e as práticas de uma candidata a professora de matemática [Explain and negotiate meanings: The conceptions and practices of a candidate for a math teacher]. In J. Matos, A. Domingos, C. Carvalho, \& P. Teixeira (Eds.), Investigação em educação matemática: comunicação no ensino da matemática (pp. 197-211). Lisboa: Sociedade Portuguesa de Investigação em Educação Matemática.

Menezes, L. (2010). Concepções sobre a comunicação matemática de uma futura professora [Conceptions about the mathematical communication of a future teacher]. In J. Matos, A. Domingos, C. Carvalho, \& P. Teixeira (Eds.), Investigação em educação matemática: comunicação no ensino e na aprendizagem da matemática [Research in mathematics education: Communication in the teaching and learning of mathematics]. Lisboa: Sociedade Portuguesa de Investigação em Educação Matemática.

Mota, D. (2014). Tarefas matemáticas para promover o raciocínio matemático de alunos do ensino básico [Mathematical tasks to promote the mathematical reasoning of elementary school students]. Relatório de Estágio: Universidade de Aveiro. http://ria.ua.pt/handle/10773/14756

NCTM. (2007). Princípios e Normas para a Matemática Escolar [Principles and norms for school mathematics]. Lisboa: APM.

NCTM. (2008). Princípios e Normas para a Matemática Escolar [Principles and norms for school mathematics]. Lisboa: APM. 
ONU. (2015). 17 Objetivos do Desenvolvimento Sustentável. Obtido em 22 de Julho [17 Sustainable Development Goals]. http://www.unric.org/pt/objetivos-dedesenvolvimento-sustentavel.

Pimenta. (2013). Tarefas de investigação para promover a comunicação matemática. Relatório Final apresentado à Universidade de Aveiro para cumprimento dos requisitos necessários à obtenção do grau de Mestre em Ensino dos $1 .^{\circ}$ e 2. ${ }^{\circ}$ Ciclo Ensino Básico [Research tasks to promote mathematical communication. Final Report presented to the University of Aveiro to fulfill the necessary requirements to obtain the Master's degree in Teaching of the $1^{\text {st }}$ and $2^{\text {nd }}$ Cycle basic education]. Aveiro: Universidade de Aveiro.

Pinto, F., \& Santos, L. (2010). A comunicação em sala de aula no desenvolvimento de uma tarefa de natureza exploratória [Communication in the classroom in the development of an exploratory task]. In J. Matos, A. Domingos, C. Carvalho, \& P. Teixeira (Eds.), Investigação em educação matemática: comunicação no ensino e na aprendizagem da matemática [Research in mathematics education: Communication in the teaching and learning of mathematics]. Lisboa: Sociedade Portuguesa de Investigação em Educação Matemática.

Ponte, J. (2009). Novo programa de matemática como oportunidade de mudança para os professores do ensino básico [New math program as an opportunity for change for primary school teachers], (pp. 96-114). http://repositorio.ipsantarem.pt/ bitstream/10400.15/340/1/L7.pdf

Ponte, J. (2008). A investigação em educação matemática em Portugal: Realizações e perspectivas [Research in mathematics education in Portugal: Achievements and perspectives]. In R. Luengo-González, B. Gómez-Alfonso, M. Camacho-Machín, \& L. B. Nieto (Eds.), Investigación en educación matemática [Research in mathematics education], (pp. 55-78). Badajoz: SEIEM.

Ribeiro, D. (2018). Apontamentos retirados em aula da unidade curricular de Investigação em Educação [Notes taken in class of the curricular unit of research in education]. Porto: ESE.

Rodrigues, M. (2010). O processo de demonstrar na aula de matemática: um olhar sobre a comunicação emergente [The process of demonstrating in mathematics class: a look at emerging communication]. In J. Matos, A. Domingos, C. Carvalho, \& P. Teixeira (Eds.), Investigação em educação matemática: comunicação no ensino e na aprendizagem da matemática [Research in mathematics education: Communication in the teaching and learning of mathematics]. Lisboa: Sociedade Portuguesa de Investigação em Educação Matemática.

Rocha, T. I. (2008). Adaptação Escolar: uma abordagem integradora das competências sociais e académicas. Tese de Mestrado em Temas de Psicologia. Faculdade de Psicologia e Ciências da Educação da Universidade do Porto [School adaptation: An integrative approach to social and academic competences]. Master's Thesis in Psychology Themes. Faculty of Psychology and Educational Sciences, University of Porto). Porto: FPCEUP.

Russell, S. (1999). Mathematical reasoning in the elementary grades. Developing mathematical reasoning in grades $K-12,1-12$. Reston, VA: NCTM. 
Schimdt, L., Guerra, J., \& Gil, J. (2008). Educação ambiental em Portugal: fomentando uma cidadania responsável. Comunicação apresentada no VI Congresso de Psicologia [Environmental education in Portugal: Fostering responsible citizenship]. Communication presented at the VI Psychology Congress.

Schimdt, L. (2005). Educação Ambiental e Educação para o Desenvolvimento Sustentável: Um Futuro Comum. (Ed.), Actas das Jornadas Pedagógicas de Educação Ambiental [Environmental education and education for sustainable development: A common future]. Proceedings of the Pedagogical Journeys of Environmental Education, 27-29.

Simões, C. M. (2009). Ultrapassar adversidades e vencer desafios: manual de promoção da resiliência na adolescência. Cruz Quebrada: FMH, Fundação para a ciência e a tecnologia, Ministério da ciência e do ensino superior [Overcoming adversity and overcoming challenges: A manual for promoting adolescent resilience]. Cruz Quebrada: FMH, Foundation for Science and Technology, Ministry of Science and Higher Education.

Sousa, F. C. (2009). Comunicação matemática: contributos do PCFM na reflexão das práticas de professores [Mathematical communication: Contributions from the PCFM to the reflection of teachers' practices]. http:/www.apm.pt/files/_CO_Sousa_ Cebolo_Alves_Mamede_4a41313eee16e.pdf

Correspondence concerning this paper should be addressed to Telma André, School of Education, Polytechnic of Porto. Email: telmaca84@gmail.com 